\title{
Art in Science
}

\section{Art in Science: Orthopaedics Through Philatelic Material}

\author{
Sarper Gursu MD, Timur Yildirim MD, \\ Vedat Sahin MD, Emine Koc
}

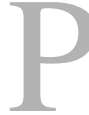
ostage stamps have often been used to educate populations on recent developments, achievements, or figures who made important

Note from the Editor-in-Chief: I am pleased to present the next installment of "Art in Science" to our CORR ${ }^{\circledR}$ readers. "Art in Science" normally is team-written by Gary and Linda Friedlaender. This month, the Friedlaenders and I are excited to offer a unique guest column by Sarper Gursu MD and colleagues who examine how stamp designers use visual imagery to convey information to those who see, collect, and use stamps. As always, this column offers observations about where art and medicine meet.

Each author certifies that he or she has no commercial associations (eg, consultancies, stock ownership, equity interest, patent/ licensing arrangements, etc) that might pose a conflict of interest in connection with the submitted article.

All ICMJE Conflict of Interest Forms for authors and Clinical Orthopaedics and Related Research ${ }^{\circledR}$ editors and board members are on file with the publication and can be viewed on request.

The opinions expressed are those of the writers, and do not reflect the opinion or policy of $C O R R^{\circledR}$ or the Association of Bone and Joint Surgeons ${ }^{\mathbb{R}}$.

\footnotetext{
S. Gursu MD $(\bowtie) \cdot$ T. Yildirim

MD · V. Sahin MD

Baltalimani Metin Sabanci Bone and

Joint Diseases Education and Research

Hospital, 34730 Istanbul, Turkey

e-mail: sarper154@yahoo.com
}

contributions to humanity $[1,12$, 19, 24]. The study of stamps and postal history, called philately, can include different areas of interest, including medical philately [3].

Previous articles have studied stamps in general medicine, radiology, cardiology, dentistry, anaesthesia, anatomy, or illnesses like tuberculosis, and cancer $[1,3,5,8,13,18-20$, 22, 23]. Stamps devoted to the orthopaedic field usually are printed (1) to honor pioneers of orthopaedics and traumatology, (2) to commemorate important orthopaedic meetings or celebrate anniversaries of national orthopaedic associations, and (3) to announce improvements in the field.

Postage stamp usage is decreasing due to improvement of faster and easier types of communication methods, including email. Still, postage stamps and First Day Covers (specially designed covers with postage stamps that have been postmarked on the day the stamps were issued by the post office) remain one of the best

E. Koc

Department of Arts History, Faculty of Literature, Ege University, Izmir, Turkey ways of distributing messages through populations.

\section{Stamps Devoted to Pioneers of Orthopaedic Surgery}

In order to convey the most important details of a historic figure's life, postage stamp artists (designers and engravers) typically use little text, choosing instead to utilize the small "canvas" they have available for imagery: a portrait, full-face bust, or pictorial surrounded by symbols unique to the subject [25]. These symbols and pictorial designs often include bright and distinct colors chosen by the designers and placed onto the stamp by engravers [25]. The stamps described below tell a story and offer a unique window into the history of some of the most influential surgeons in the history of our specialty.

In 1964, the U.S. Postal Service issued a stamp (Fig. 1) honoring Drs. William (1861-1939) and Charles Mayo (1865-1939), brothers who established The Mayo Graduate School of Medicine in 1915, widely considered the country's first graduate program in clinical medicine [15]. The Mayo brothers encouraged their staff 


\section{Art in Science}

to focus on specialized medicine and integrated patient care. This incredible foresight led to the development of numerous clinical specialties, including orthopaedics [15].

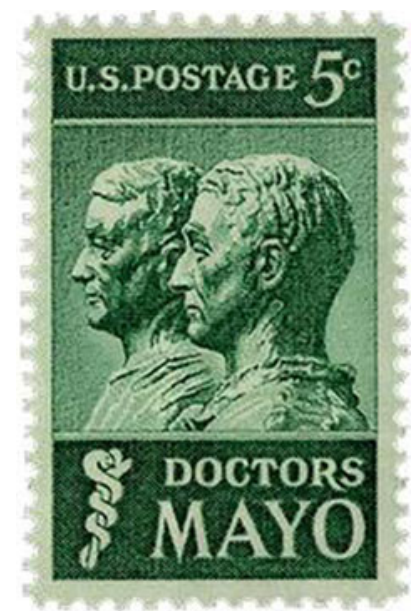

Fig. 1 The U.S. Postal Service stamp shows the Mayo brothers, along with the staff of Asclepius, who is considered the Greek God of health and healing.
Issued in Rochester, Minnesota, the home of the famed clinic, the 5-cent US stamp features bronze busts of the Mayo brothers designed by prominent American sculptor James Earle Fraser [17]. The bureau of engraving and printing printed the stamp in green [17], which is often considered the symbolic color of nature and healthy living. The stamp also shows the staff of Asclepius, the Greek God of health and healing, on the lower left corner. The caduceus, which looks similar to the staff of Asclepius, has been recognized as the symbol of American Naval hospitals since 1856. After 1902, the caduceus was recognized as the symbol of all American military hospitals [11].

The staff of Asclepius can also be found in a stamp dedicated to Adolf Lorenz (1854-1946). Shortly after graduating from medical school, Lorenz developed a severe allergy to carbolic acid, which was often found

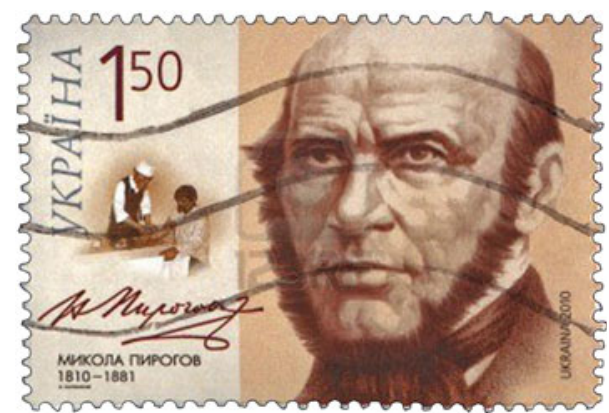

Fig. 2 Russia commemorated Nikolay Pirogov with a stamp and First Day Cover in 2010.

in operating rooms at the time. Unable to perform in the operating room, Lorenz concentrated on nonoperative treatments. Lorenz became known for his closed reduction technique for congenital dislocation of the hip. In 1997, Austria honored him with a stamp printed for "The Orthopaedic Congress." Designed by Maria Siegl, the stamp included a portrait of Lorenz, along with a bowed tree, representing Science of Orthopaedics. The rope around the tree symbolizes the snake, coiled to the staff of Asclepius.

Nikolay Pirogov (1810-1881) (Fig. 2) is considered one of the first surgeons to use ether as an anesthetic. $\mathrm{He}$ developed his own technique of amputation known as "Pirogov Amputation." İ 2010, stamps with his portrait were printed in Ukraine and Russia to commemorate his 200th birthday, as well as his contributions to orthopaedic surgery.

The French physician, Jean Martin Charcot (1825-1893) is considered the "Father of French Neurology," but he is still recognized for his contributions to orthopaedics [16]. In 1960, France honored him with a stamp and a First Day Cover, designed by Charles Mazelin and engraved by Claude Durrens. The Charcot First Day Cover is one of the earliest examples of a stamp displaying an important orthopaedic figure. A portrait of Charcot 


\section{Art in Science}

and a picture of The Pitié-Salpêtrière Hospital, where he used to work appeared on the stamp. The image on the First Day Cover is reproduced from the oil painting $U n$ Leçon Clinique à la Salpêtrière by French artist Pierre-Andre Brouillet in 1887. In the picture, Charcot is demonstrated giving a lecture to his colleagues.

Marie François Xavier Bichat (1771-1802) is known for his contribution to histology. In 1959, he was honored with a stamp and a First Day Cover. His work, Physiological Research on the Life and Death, was symbolized on the stamp by the two torches placed at each side of his head. The picture on the First Day Cover was inspired from the book, Anatomie Générale: Appliquée à la Phsyiologie et à la Médecine, which was printed in 1812, in Paris [6].

Many subspecialties in medicine, regard Hippocrates as the first representative of their specialty. Postal offices around the world released stamps with Hippocrates, like the one printed in his home, Greece, in 1979. On this stamp, the original marble statue of Hippocrates, which is now in his birthplace of Kos, can be seen. A reproduction of this bust has been presented to The University of Montpelier, one of the oldest medical schools of Europe, by the municipality of Kos to be exhibited along with the other bust of Hippocrates, which was donated to the university some 200 years ago by Napoleon Bonaparte. This statue of Hippocrates is widely accepted as his vision worldwide and being used to symbolize him in the academic world. The Greek stamp showed Hippocrates in front of his famous oath.

Ambroise Paré (1510-1590), made significant contributions to orthopaedics and traumatology. A royal surgeon, Paré proved the harmfulness of treating gunshot wounds with boiling oil and used ligature in amputation. Paré was comemmorated with a stamp in 1943, in France. Georges-léo Degorce (1894-1943) designed and engraved the stamp using Paré's portrait. While the original portrait used to be preserved in Cateau d'Azay-le-Rideau, it was later presented to The Academy of Surgery.

Jean Alfred Fournier (1832-1914) described what is known as "Fournier's Tibia," which is the thickening and anterior bowing of the tibia due to congenital syphilis [7]. Two stamps with Fournier's portrait were issued in 1946 and 1947 in France. The stamps were designed by Paul Pierre Lemagny (1905-1977) and engraved by Charles Paul Dufresne (1885-1956). The picture of Fournier, showing his profile, was adopted from the bronze medallion and designed by Priest Jules from Clement for Fournier's 70th birthday in 1902. The revenue of this charity stamp went to The French Society for Sanitary and Moral Prophylaxis, whose founder was Fournier [9]. The organizations involved and the public complained about the small amounts printed and this led to a reedition of the highly in-demand stamp.

Mary Walker (1832-1919) served as an U. S. Army surgeon during the Civil War. In the war, the Confederate Army captured her as a spy after she crossed enemy lines to treat wounded civilians [21]. The Medal of Honor, which she was awarded for her efforts, can be seen in her portrait. On her 150th birth year, a stamp and First Day Cover were issued to commemorate her accomplishments.

The Turkish physician, Ibni Sina (980-1037), also known as Avicenna, studied in many areas of medicine. His worldwide famous medical book, Canon of Medicine, includes many issues, some of which are related to orthopaedics and traumatology. The other issues include: anatomy of the musculoskeletal system, treatment of fractures and dislocations, soft tissue and tendon injuries, and treatment of bone infections [2]. On his 1000th birth year, many countries issued two stamps for Ibni Sina. That same year, Turkey released a First Day Cover. Two years later, another First Day Cover was released detailing The International Ibni Sina Symposium. In 
this First Day Cover, the pattern showing two snakes coiling to each other, is originated from the Seldjukian stone art.

Other pioneers who have been commemorated with a stamp include, Antonius Mathijsen [16], Emile Letournal [16], Lorenz Böhler, Joseph Trueta [10, 14], and Abu al-Qasim Khalaf ibn al-Abbas Al-Zahrawi [4].

\section{Stamps Announcing Major Orthopaedic Congresses}

Some postal offices issue stamps and First Day Covers for meetings or events held in their countries. These stamps are called commemoratives, according to the American Philatelic Society. The postal service cancels each of these First Day Covers on the day they were announced. The covers are then placed on sale and released during the meetings. All First Day Covers have figures on the left side of the covers, called "cachet," which offers information about the meetings.

\section{Stamps Celebrating Anniversaries of National Orthopaedic Associations}

In many countries, post offices issue stamps to celebrate anniversaries of establishment of national associations.
Orthopaedic associations of Phillippine, Egypt, Colombia, and India were commemorated by special postage stamps or First Day Covers.

In 2010, the UK's Royal Mail released a stamp to commemorate the first hip arthroplasty performed by John Charnley in 1962. In 1992, the SARAH Network of Rehabilitation Hospitals, which is comprised of nine hospitals in Brazil, appeared on a memorial stamp.

\section{Conclusion}

Despite faster communication methods, stamps and other philatelic materials remain an important means of delivering information to the general population. Through the use of easily identifiable symbols and imagery, stamp designs illuminate the visual history of our specialty by depicting pivotal figures and important events.

Acknowledgments The authors would like to thank Peter Kelly from French \& Colonies Philatelic Society (UK), Paul McGowan from Netherlands Philatelic Circle, and Ulrike Radl from Österreichische Post AG for their valuable help and contribution to our study.

\section{References}

1. Afshar A. A brief Iranian medical history through commemorative postage stamps. Arch Iran Med. 2010;13:161-165.
2. Afshar A. Concepts of orthopedic disorders in Avicenna's Canon of Medicine. Arch Iran Med. 2011;14:157-159.

3. Afshar A. Honoring Avicenna, the great Persian physician on the world's postage stamps, Arch Iran Med. 2010;135:447-453.

4. Al-Rodhan NR, Fox JL. Al-Zahrawi and Arabian neurosurgery, 936-1013 AD. Surg Neurol.1986;26:92-95.

5. Andrews MJ. Medical history as portrayed on postage stamps. J Natl Med Assoc. 1956;48:1-9.

6. Bichat X. Anatomie Générale: Appliquée à la Phsyiologie et à la Médecine. Paris, France: Brosson; 1812:1-244.

7. Brzezinski P, Gijon EG, Lopez-Lopez J, Toyokawa T, Scrimshaw NS, Malard O, Bimbi C. Dermatology eponyms-phenomen/sign-lexicon (f). Our Dermatol Online. 2012;3:66-78.

8. Davies MK, Hollman A. Stamps in cardiology: millennium stamps. Heart. 2006;92:146.

9. Haas LF. Jean Alfred Fournier (1832-1914). J Neurol Neurosurg Psychiatry. 1998;65:373.

10. In memoriam. Joseph Trueta. 1897-1977. J Bone Joint Surg Br. 1977;59:243-245.

11. Johnson TG. The Medical Staff Debate: Cadeuces or Aesculapius? Chicago Tribune. May 21, 1985.

12. Lefrere JJ, Danic B. Transfusion, blood donation, and postage stamps: a worldwide review. Transfusion. 2010;50:1838-1848.

13. Loevy HT, Kowitz AA. Dentistry on stamps: a commemorative stamp on dental health. J Hist Dent. 2008;56:44.

14. Matthews JL, Goodfellow JW. Joseph Trueta 1897-1977. Clin Orthop Relat Res. 1981;156:5-7. 


\section{Art in Science}

15. Mayo Clinic. History of surgery at the mayo clinic. Available at: http:// www.mayoclinic.org/surgery/history.html . Accessed on Aug. 30, 2013.

16. Mostofi SB. Who's who in Orthopedics, Springer, USA, 1985.

17. Mystic Stamp Company. 1964 5c doctors mayo - catolog \#1251. Available at: http://www.mysticstamp.com/ viewProducts.asp?sku=1251 . Accessed on Aug. 30, 2013.
18. O'Rahilly R. Philatelic introduction to the history of anatomy. Clin Anat. 1997;10:337-340.

19. Praestholm J, Dissing I, Herning M. Radiology on postage stamps. Radiographics. 1998;8:981-986.

20. Rangappa P. History of analgesia and regional anesthesia through philately. Anaesth Intensive Care. 2008;36 (suppl 1):12-18.

21. Rutkow IM. Mary Edwards Walker. Arch Surg. 2000;135:489.
22. Shampo MA, Rosenow EC. A history of tuberculosis on stamps. Chest. 2009;136:578-582.

23. Taub M. Cancer stamps: 50 years in the crusade against cancer through stamps. CA Cancer J Clin. 1978;28:164-169.

24. Titford M. Postage stamps fading as medical education tool. South Med J. 2009;102:707-710.

25. Williams LN. Fundamentals of Philately. Bellefonte, PA: American Philatelic Society; 1990: 1-892. 